\title{
PELATIHAN PENYUSUNAN MODUL KONDISIONAL PEMBELAJARAN LURING
}

\section{TRAINING OF CONDITIONAL MODULE PREPARATION FOR OFFLINE LEARNING}

\author{
Revita Yuni ${ }^{1)}$, Suci Frisnoiry ${ }^{2)}$, Gita Noveri Eza ${ }^{3)}$ \\ ${ }^{1}$ Program Studi Pendidikan Ekonomi, Fakultas Ekonomi, Universitas Negeri Medan \\ ${ }^{2}$ Program Studi Pendidikan Matematika, Fakultas Matematika dan Ilmu Pengetahuan \\ Alam, Universitas Negeri Medan \\ ${ }^{3}$ Program Studi PG PAUD, Fakultas Ilmu Pendidikan, Universitas Negeri Medan \\ ${ }^{1}$ Email: revitayuni25@gmail.com
}

\begin{abstract}
Abstrak: Program Pengabdian kepada Masyarakat (PKM) tentang pelatihan penyusunan modul kondisional untuk pembelajaran luar jaringan (luring). Kegiatan PKM ini dilaksanakan di SD Swasta Wira Mandiri Medan. Pada situasi pandemi Covid-19, SD Swasta Wira Mandiri Medan memberlakukan sistem Belajar Dari Rumah (BDR) sesuai dengan anjuran Pemerintah untuk memutuskan rantai penularan Virus Covid-19. Guruguru SD Swasta Wira Mandiri Medan masih sangat membutuhkan pelatihan dalam melaksanakan pembelajaran dari rumah yang dilakukan dengan sistem online atau yang dikenal dengan istilah pembelajaran dalam jaringan (daring) dan pembelajaran luar jaringan (luring). Berdasarkan hasil observasi awal dan wawancara ditemukan permasalahan yang dialami oleh mitra yaitu: (1) Kurangnya pengetahuan guru penyusunan bahan ajar yang efektif untuk pembelajaran daring maupun luring (2) BDR dilaksanakan hanya menggunakan LKPD sederhana sehingga interaksi hanya satu arah, (3) Kurangnya pelatihan untuk pembelajaran daring ataupun panduan dalam penyusunan bahan ajar yang interaktif. Metode pendekatan yang diterapkan dalam pelaksanaan PKM ini yaitu metode pelatihan, praktik dan pendampingan. Keberhasilan pelaksanaan kegiatan PKM ini terukur dari luaran yang dihasilkan bahan ajar berupa modul bersifat kondisional yang interaktif dan artikel ilmiah.
\end{abstract}

Kata Kunci: Pelatihan, Bahan ajar, Modul Kondisional

\begin{abstract}
The community Service Program are about training of conditional module preparation for offline learning. The activities are implemented in Wira Mandiri Private Elementary School Medan. In this pandemic situation, Wira Mandiri Private Elemantary School apply Work From Home (WFH) system as an instruction from the goverment to cut off the chain of transmission of Covid-19 virus. Teachers in Wira Mandiri Private Elementary School still need a courses and training to teach the students with online and offline learning in WFH system. Based on observation result and interview, problems that was found are : (1) lack of teachers' knowledge of effective learning materials preparation for online and offline learning, (2) WFH used simple students worksheets so that only one way learning, and (3) lack of training in preparation of interacitive learning material. Approach method that applied in this Community Service Program was training, practice, and accompaniment method. The success of implementing this activities are measured from the output produced namely interactive conditional learning material and scientific article.
\end{abstract}

Keywords: Training, learning materials, and conditional module 


\section{INTEGRITAS : Jurnal Pengabdian}

Vol 4, No 2, Desember 2020

ISSN $2580-7978$ (cetak) ISSN 2615-0794 (online)

\section{PENDAHULUAN}

Berdasarkan hasil wawancara dengan Kepala Sekolah SD Swasta Wira Mandiri Medan Bapak M. Wirahadinusa P. Kaya Harahap, S.I.Kom diperoleh informasi bahwa guru-guru di SD Swasta Wira Mandiri masih sangat minim pengetahuannya mengenai penyusunan bahan ajar berupa modul untuk daring maupun luring. Guru-guru hanya memanfaatkan LKPD berupa soal-soal sebagai media penghubung proses pembelajaran dengan siswa. Kurangnya pengetahuan bahan ajar yang interaktif membuat guru-guru tidak dapat memaksimalkan pembelajarannya. Oleh karena itu, bahan ajar berupa modul kondisional menjadi andalan karena modul disusun berdasarkan SK dan KD diturunkan menjadi tujuan pembelajaran menggunakan bahasa sederhana. Bahasa dibuat seperti guru mengajar dikelas sehingga terjadi interaksi antar guru dengan siswa melalui bahan ajar berupa modul. Penyusunan tujuan pembelajaran disusun berdasarkan kata opersional taksonomi bloom mulai dari C1 sampai C6.

LKPD yang digunakan guru sekarang disusun berupa soal-soal yang harus di jawab siswa selama belajar dari rumah. Sehingga LKPD tersebut tidak membentuk karakter siswa karena penilaian hanya berdasarkan kognitif tanpa mempertimbangan afektif dan psikomotor. Modul disusun berdasarkan inisiatif guru sendiri. LKPD di susun sebagai solusi pembelajaran jarak jauh atau BDR bagi guru untuk siswa. Hal ini dilakukan semenjak keluarnya surat edaran penyelenggaraan pembelajaran dilakukan secara luring. Berdasarkan wawancara dengan salah satu guru SD Swasta Wira Mandiri, menyatakan bahwa tidak semua orang tua siswa memiliki fasilitas berupa handphone untuk pembelajaran daring (dalam jaringan). Sehingga penyusunan LKPD sederhana menjadi solusi agar proses belajar mengajar dapat berjalan sebagai mana mestinya.

Penyerahan LKPD dilakukan 2 kali dalam satu minggu tatap muka dengan mematuhi protokoler kesehatan. Dalam satu kali pertemuan hanya 2 jam untuk semua mata pelajaran. Sehingga proses belajar mengajar hanya satu arah, mengakibatkan kurangnya interaksi antara siswa dengan guru sebagi tenaga pendidik. Akibat dari itu adalah kurangnya proses pembentukan karakter siswa 


\section{INTEGRITAS : Jurnal Pengabdian}

Vol 4, No 2, Desember 2020

ISSN $2580-7978$ (cetak) ISSN 2615 - 0794 (online)

berdasarkan karakteristik materi pembelajaran. Sering siswa merasa bosan dan putus aja dengan belajar seperti demikian. Rasa bosan terjadi karena kurangnya interaksi siswa dengan siswa dan siswa dengan guru.

Selama ini guru sangat minim mendapatkan pelatihan untuk penyusunan bahan ajar yang interaktif. Bahan ajar berupa modul interaktif sehingga siswa dapat belajar secara mandiri dan merasakan kehadiran guru. Guru sangat mengharapkan mendapatkan pelatihan seperti demikian guna menambah wawasan dan ilmu pengetahuan untuk menuju guru professional. Guru professional adalah guru yang mampu beradapatasi perkembangan teknologi dan juga situasi dan kondisi terkini sehingga proses belajar mengajar dapat berjalan secara aktif dan interaktif.

Pada situasi pandemi Covid-19, kegiatan pembelajaran dilakukan dari rumah sesuai dengan anjuran pemerintah untuk memberlakukan social distancing demi memutus rantai penularan virus Covid-19. Kegiatan ini merupakan suatu tantangan sekaligus keuntungan bagi guru- guru untuk meningkatkan keprofesionalannya melalui media belajar yang dirancang untuk pembelajaran online (daring) maupun Offline (Luring)

Berdasarkan analisis situasi di atas, solusi mendasar yang dibutuhkan oleh guru SD Swasta Wira Mandiri Medan adalah perlu diadakan pelatihan kepada guru-guru untuk menyusun bahan ajar berupa modul kondisional yang dapat digunakan siswa secara mandiri. Sehingga terjadi interaksi antara guru dengan siswa ketika belajar dengan modul. Harapannya proses pembelajaran terjadi secara aktif dan interaktif.

Permasalahan yang dihadapi mitra yaitu SD Swasta Wira Mandiri Medan adalah sebagai berikut: (a) Kurangnya pengetahuan guru dalam penyusunan bahan ajar yang interaktif, (b) BDR dilaksanakan hanya menggunakan LKPD sederhana berupa kumpulan soal-soal, dan (c) Kurangnya pelatihan untuk pembelajaran daring ataupun luring. 


\section{INTEGRITAS : Jurnal Pengabdian}

Vol 4, No 2, Desember 2020

ISSN 2580 - 7978 (cetak) ISSN 2615 - 0794 (online)

\section{METODE}

Metode pelaksanaan pada kegiatan Tahapan pelaksanaan PKM ini dibagi menjadi empat tahapan besar yang akan dirinci sebagai berikut:

1. Analisis awal/Analisis kebutuhan

Kegiatan awal yang dilakukan adalah koordinasi dengan mitra dalam hal ini adalah kepala sekolah. Selanjutnya Koordiansi antar tim dalam menyiapkan segala hal yang diperlukan

2. Pelaksanaan

Pelaksanaan kegiatan ini dilakukan setelah persiapan atau seluruh koordinasi baik antar tim maupun tim dengan mitra, adapun persiapan diantaranya pemberian informasi dan fasilitas pelatihan penyusunan bahan ajar berupa modul kondisional

3. Proses pelaksanaan

Pada tahap awal pelaksanaan, tim pengabdi sebagai fasilitator dan narasumber memberikan pengertian apa yang dimaksud bahan ajar, modul interaktif. Setelah itu dilakukan dengan pelatihan penyusunan modul kondisional.

4. Tahap Evaluasi

Pada tahap ini pelaksana akan memantau kelancaran dan perampungan guru dalam penyusunan modul sehingga menghasilkan sebuah modul kondisional yang utuh.

\section{HASIL DAN PEMBAHASAN}

Tim pengabdian melakukan kunjungan dan observasi proses belajar mengajar di SD Wira Mandiri selama pandemic covid-19 tanggal 29 September 2020. Setelah mendapatkan informasi langsung dari kepala sekolah, tim pengabdian menawarkan solusi pembuatan media pembelajaran Belajar Dari Rumah (BDR) agar proses pembelajaran menjadi aktif dan efektif. Selanjutnya mengarahkan kepada guru peserta pelatihan untuk menyiapkan silabus sesuai dengan bidang studi masing-masing.

Tanggal 20 Oktober 2020 dilakukan kegiatan pengabdian berupa penyampaian materi pelatihan secara tatap muka dengan menerapkan protokol 


\section{INTEGRITAS : Jurnal Pengabdian}

Vol 4, No 2, Desember 2020

ISSN $2580-7978$ (cetak) ISSN 2615 - 0794 (online)

kesehatan dari narasumber di ruang kelas SD Wira Mandiri Medan. Narasumbernya selain tim pengabdian, juga ada dari Bapak Roni Afriadi, M.Pd selaku Fasilitator Dosen Tanoto Foundation TTI Sumatera Utara yang diundang oleh tim pengabdian. Tanoto Foundation merupakan suatu yayasan yang berperan aktif dalam meningkatkan kualitas pendidikan Indonesia.

Materi yang diberikan yaitu tentang unsur-unsur modul, analisis Kompetensi Dasar (KD) untuk menetapkan tujuan pembelajaran, bentuk-bentuk pertanyaan pada lembar kerja siswa, dan praktek penyusunan modul oleh setiap guru sesuai dengan bidang studi masing-masing.

Tanggal 5 November 2020 dilakukan evaluasi modul yang telah disusun oleh guru. Kegiatan ini dilakukan secara daring. Guru mengirim modul yang telah disusun melalui aplikasi whatsApp. Selanjutnya dilakukan evaluasi dan validasi modul berdasarkan standar modul luring. Evaluasi dan validasi modul berdasarkan unsur-unsur modul baik dari segi tampilan modul, bahasa modul, susunan modul, dan alat evaluasi modul. Setelah divalidasi modul dikirim kembali ke sekolah untuk dapat diterapkan dalam proses belajar mengajar selama Belajar Dari Rumah (BDR).

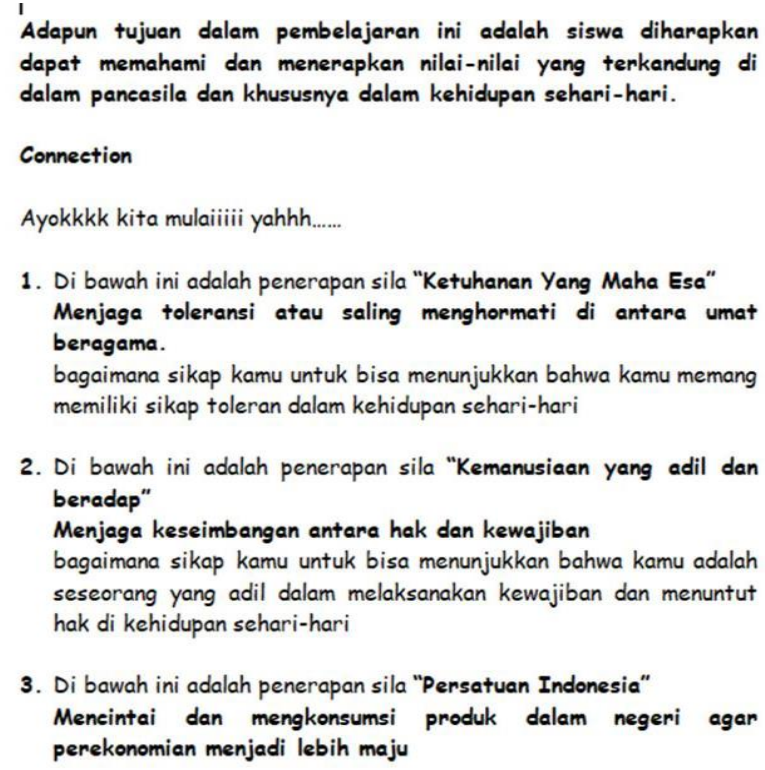

Gambar 1. Modul Sebelum Revisi 


\section{INTEGRITAS : Jurnal Pengabdian}

Vol 4, No 2, Desember 2020

ISSN 2580 - 7978 (cetak) ISSN 2615 - 0794 (online)

tujuan dalam pembelajaran kita kali ini adalah agar Anak-anak Umi memahami dan menerapkan nilai-nilai yang terkandung di dalam pancasila untuk di terapkan dalam kehidupan sehari-hari.

Ayokkkk kita mulaiiiii yahhh......

1. Di bawah ini adalah penerapan sila "Ketuhanan Yang Maha Esa" Menjaga toleransi atau saling menghormati di antara umat beragama.

bagaimana sikap kamu untuk bisa menunjukkan bahwa kamu memang memiliki sikap toleran dalam kehidupan sehari-hari

Silahkan tulis jawabanxa xa: missal: menghargai teman2 lain yang berbeda agamavere

2. Di bawah ini adalah penerapan sila "Kemanusiaan yang adil dan beradap"

Menjaga keseimbangan antara hak dan kewajiban bagaimana sikap kamu untuk bisa menunjukkan bahwa kamu adalah seseorang yang adil dalam melaksanakan kewajiban dan menuntut hak di kehidupan sehari-hari

Silabkan tulis jawabanxa xa; missal: disekolah hak mendapatkan pengajaran atau belajar yang tekun sedangkan kewaiiban membavar SPP, silahkan sontoh yang lain

Gambar 2. Modul Setelah Revisi

\section{Ayo, Belajar dari Rumah!}

Modul Sekolah Dasar

\section{KELAS 6}

\section{Madul ini milik}

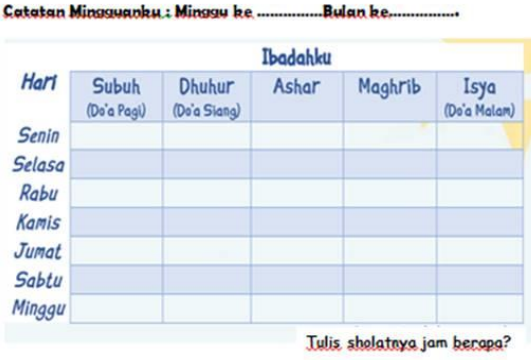

Tuliskan kebaikan apa yang kamu lakukan hari ini?

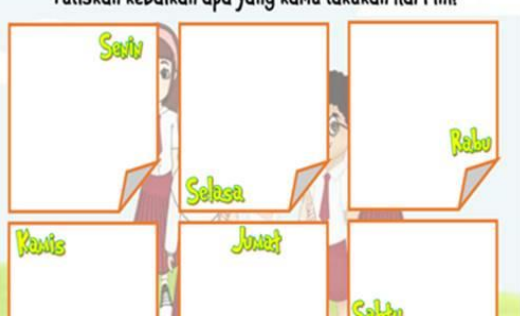




\section{INTEGRITAS : Jurnal Pengabdian}

Vol 4, No 2, Desember 2020

ISSN 2580 - 7978 (cetak) ISSN 2615 - 0794 (online)

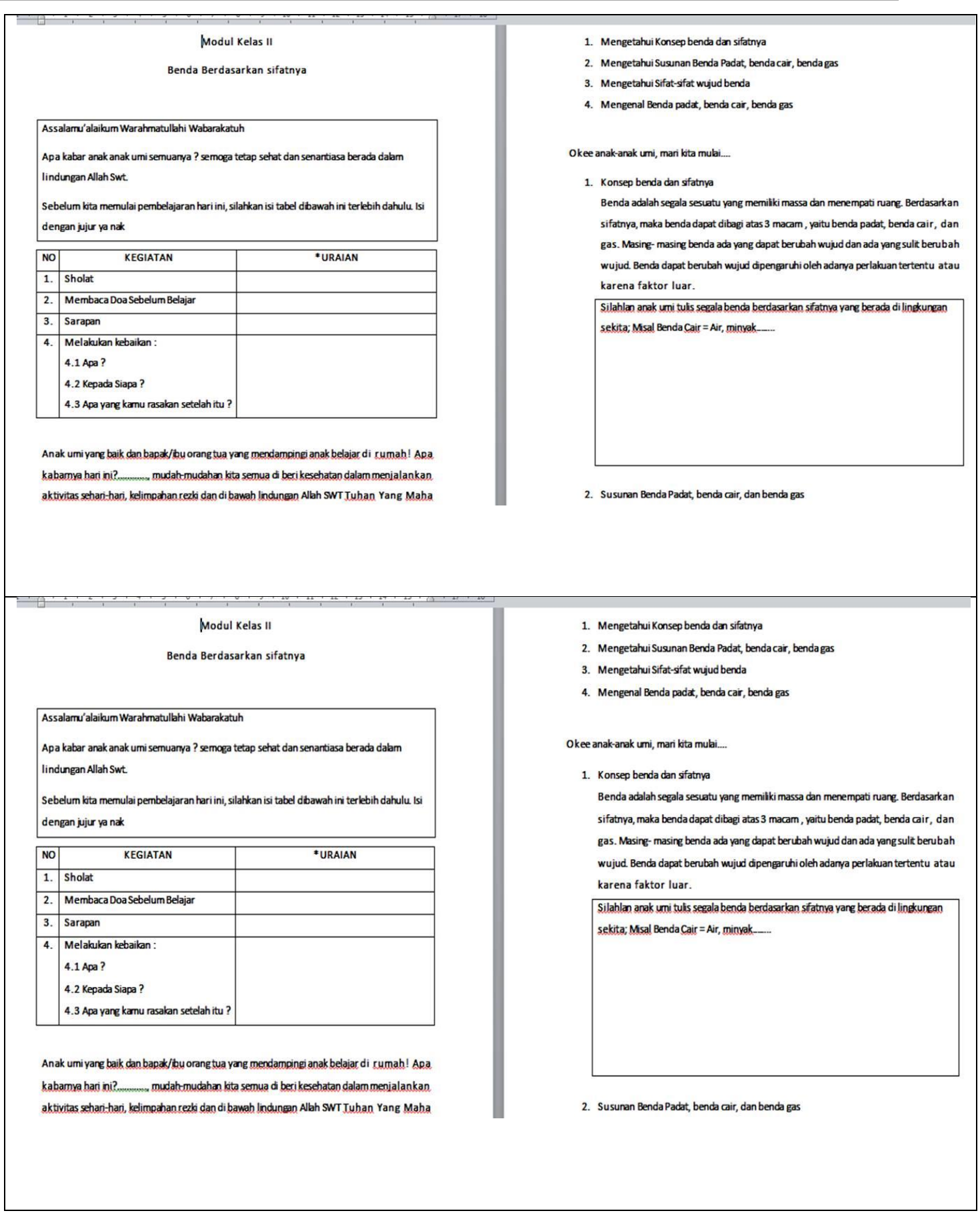


INTEGRITAS : Jurnal Pengabdian

Vol 4, No 2, Desember 2020

ISSN 2580 - 7978 (cetak) ISSN 2615 - 0794 (online)

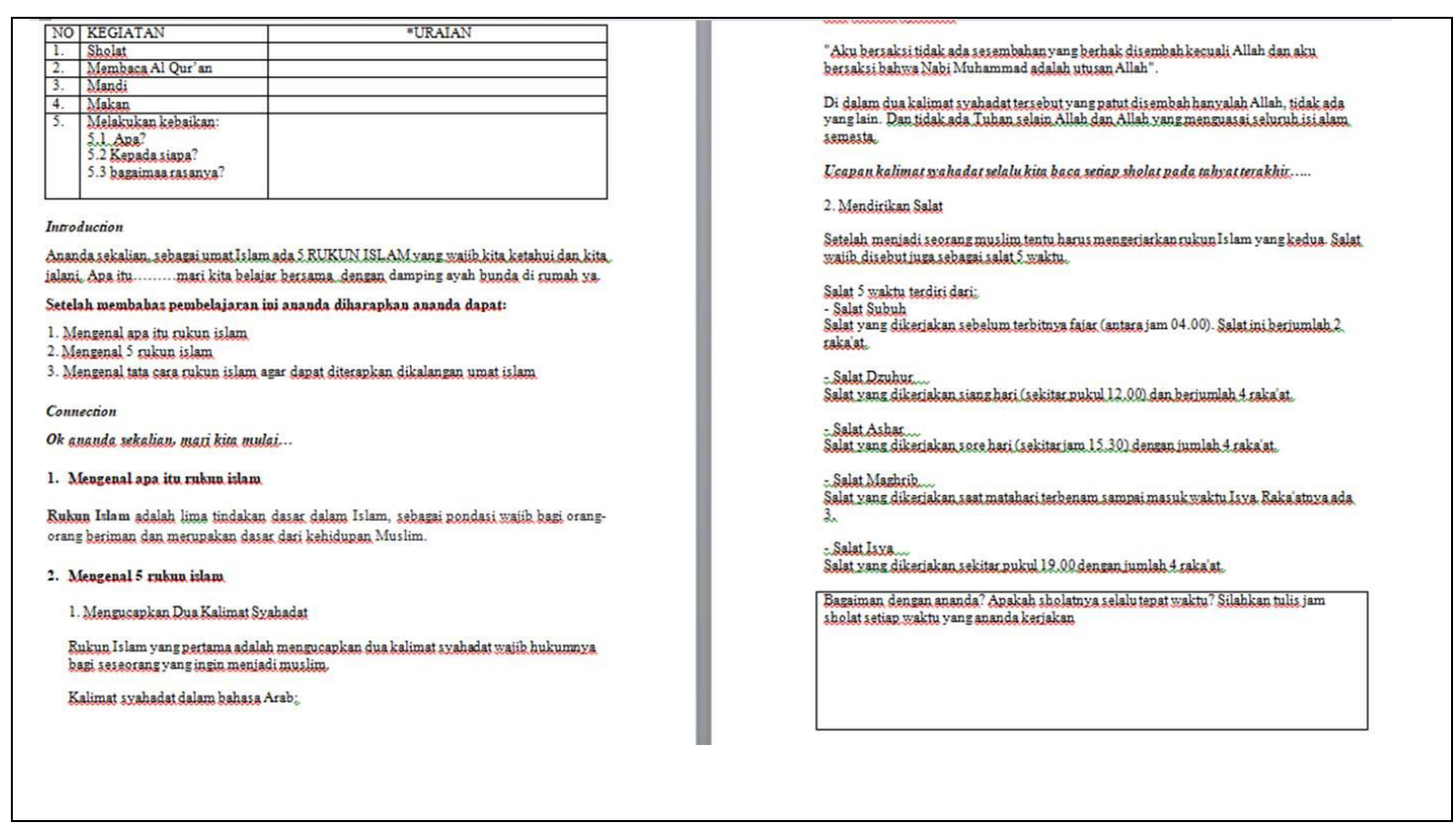

Gambar 3. Modul akhir yang Dibuat oleh Guru

\section{KESIMPULAN}

Berdasarkan analisis permasalahan yang telah dijelaskan sebelumnya, maka kesimpulan dijabarkan pada tabel berikut:

Tabel 1. Solusi dan Luaran yang Dicapai

\begin{tabular}{llll}
\hline No & $\begin{array}{l}\text { Permasalahan } \\
\text { Prioritas }\end{array}$ & \multicolumn{1}{c}{ Solusi } & \multicolumn{1}{c}{ Luaran } \\
\hline 1 & $\begin{array}{l}\text { Kurangnya } \\
\text { pengetahuan guru } \\
\text { dalam penyusunan } \\
\text { bahan ajar yang } \\
\text { interaktif }\end{array}$ & $\begin{array}{l}\text { Memberikan arahan untuk } \\
\text { menyusun bahan ajar berupa } \\
\text { modul kondisional yang } \\
\text { interkatif yang dapat dipakai } \\
\text { siswa secara mandiri dan juga } \\
\text { siswa merasakan kehadiran } \\
\text { guru saat belajar dengan modul }\end{array}$ & $\begin{array}{l}\text { Terlaksananya pelatihan } \\
\text { sehingga guru-guru } \\
\text { menjadi lebih terinspirasi } \\
\text { dan mengetahui cara } \\
\text { menyusun modul yang } \\
\text { interaktif }\end{array}$ \\
\hline 2 & $\begin{array}{l}\text { BDR dilaksanakan } \\
\text { hanya menggunakan } \\
\text { LKPD sederhana } \\
\text { berupa soal-soal }\end{array}$ & $\begin{array}{l}\text { Memperkenalkan bahan ajar } \\
\text { berupa modul kondisional }\end{array}$ & $\begin{array}{l}\text { Terlaksananya pelatihan } \\
\text { sehingga guru-guru } \\
\text { mengetahui bahan ajar }\end{array}$ \\
& $\begin{array}{l}\text { Kurangnya pelatihan } \\
\text { untuk pembelajaran } \\
\text { daring maupun }\end{array}$ & $\begin{array}{l}\text { Memberikan pelatihan } \\
\text { penyusunan bahan ajar modul } \\
\text { luring }\end{array}$ & $\begin{array}{l}\text { Terlaksananya pelatihan } \\
\text { sehingga guru-guru } \\
\text { kondisional }\end{array}$ \\
& maupun luring & $\begin{array}{l}\text { menyusun bahan ajar } \\
\text { yang interaktif untuk } \\
\text { pembelajaran daring } \\
\text { maupun luring }\end{array}$ \\
\hline
\end{tabular}


INTEGRITAS : Jurnal Pengabdian

Vol 4, No 2, Desember 2020

ISSN 2580 - 7978 (cetak) ISSN 2615 - 0794 (online)

\section{UCAPAN TERIMA KASIH}

Penulis mengucapkan terima kasih kepada pihak-pihak yang paling berkontribusi dalam pelaksanaan kegiatan pengabdian kepada masyarakat yaitu Fasilitator Dosen dari Tanoto Foundation TTI Sumatera Utara, Bapak Roni Afriadi, M.Pd., Ibu Ir selaku Ketua Yayasan Pendidikan Wiranusa Pratama dan Bapak Wira selaku Kepala Sekolah SD Wira Mandiri, serta 13 orang Bapak/Ibu Guru yang hadi dan mengikuti kegiatan yang berlangsung.

\section{DAFTAR PUSTAKA}

Arief, R \& Umniati N, 2012, Pengembangan Virtual Class Untuk Pembelajaran Augmented Reality Berbasis Android, Jurnal Pendidikan Teknologi dan Kejuruan, Volume 21, Nomor 2, Oktober 2012 (diunduh tanggal 9 mei 2020).

Budi, N E, 2017, Penerapan Pembelajaran Virtual Class Pada Materi Teks Eksplanasi Untuk Meningkatkan Aktivitas Dan Hasil Belajar Bahasa Indonesia Siswa Kelas Xi Ips 2 Sma 1 Kudus Tahun 2017, Jurnal Pendidikan Ilmu Sosial, Vol 27 No.2 (diunduh pada tanggal 10 Mei 2020).

Rohani, A \& Ahmadi, A 1991,Pengelolaan Pengajaran, Rineka Cipta, Jakarta.

Sarwa, 2019, Manajemen Kelas dan Pengembangan Instrumen Secara Daring, Medan.

Sudiana, R , Fatah, A \& Khaerunnisa, E, 2017, Kemandirian Belajar Mahasiswa Melalui Pembelajaran Berbasis Virtual Clas, JPPM Vol 10 No. 1. (diunduh tanggal 10 Mei 2020)

Susilana,R \& Riyana, C 2007, Media Pembelajaran, CV Wacana Prima, Bandung. Asrori, M 2007, Psikologi Pembelajaran, CV Wacana Prima, Bandung. 